\title{
Current Standardization and Suggestion on Development Level Evaluation of China's Characteristic Towns
}

\author{
Tan Qiqi ${ }^{1, a}$, Yun Zhenyu ${ }^{1 *}$, Hu Liangbing ${ }^{1}$, Ma Xiaolei ${ }^{1}$, Zhang Yao ${ }^{1}$, Wang Yutong ${ }^{1}$ \\ ${ }^{1}$ China National Institute of Standardization, Beijing, China \\ ${ }^{*}$ Corresponding author: Yun Zhenyu
}

\begin{abstract}
The construction of characteristic town which derives from Zhejiang is a new exploration for Zhejiang Province to adapt to the economic development. Being reliant on the construction experience of small towns in Zhejiang and other provinces and municipalities, China puts forward the requirement for the construction of characteristic towns nationwide. The development level of characteristic towns nationwide is an important factor which influences the regional economic transformation and upgrading and drives the new urbanization and new rural construction. Based on the analysis of development level and current standardization of characteristic towns, relevant suggestions are raised on the characteristic and sustainable development of characteristic towns.
\end{abstract}

\section{Introduction}

In the "work in cooperation with a due division of labor" theory put forward by Adam Smith in the Wealth of Nations, "economies of scale" theory raised by Marshall and the later industrial location theory, growth pole theory and technical innovation theory, the location agglomeration, population agglomeration and technology agglomeration of industrial economy are continuously deduced[1]. The accumulation and sedimentation of these elements may directly promote the development of a zone in a medium and large city, for example, various kinds of economic development areas, or indirectly evolutive characteristic towns based on an industry[2]. Most foreign characteristic towns take shape due to the regional development of industrial agglomeration on the basis of characteristic industry, and they gradually develop the secondary industry and the tertiary industry, and finally achieve the three-industry linkage and become the well-known classic characteristic towns[3].

The town construction in the Western Countries also invisibly leaves impacts on the thought about the integrated urban-rural construction in China's urbanization process. China's urbanization process has endured a difficult development exploration period. From the heavy industry dominated resource intensive industry to the technical research \& development and service industry dominated development model, China's economic development has undergone the high-speed growth in the earlier stage to the steady progress and then the current economic downturn pressure. Therefore, developing a new economic growth point and accelerating the transformation and upgrading of industrial structure become the key to-be-settled issues in China presently. To put forward and develop the "characteristic towns" is a beneficial exploration into how to enhance the regional competitiveness and how to carry forward the supply side reform and other issues in the new normal of China's economic development[4].

In April 2015, Zhejiang Province issued the first Planning Guide to the Creation of Characteristic Towns and the Guiding Opinions on Accelerating the Planning and Construction of Characteristic Towns in China, laying down detailed provisions for the planning area and future construction goal of characteristic town construction in Zhejiang Province. As President Xi Jinping fully recognizes the characteristic town construction in Zhejiang, and relevant ministries and commissions of the State issue the policies, the provinces and municipalities put forward the construction of a batch of characteristic towns in succession.

In October 2016, the Ministry of Housing and UrbanRural Development released the list of the first batch of 127 characteristic towns in China. The National Development and Reform Commission, China Development Bank, China Everbright Bank, China Enterprise Confederation, China Enterprise Directors Association and China Urbantownization Promotion Council jointly organize and implement "A Thousand Enterprises and Towns Project" in the construction of beautiful characteristic town. In 2017, the Ministry of Sports, the Ministry of Agriculture and other ministries and commissions issued relevant documents in succession to drive the construction of sports and leisure, agricultural characteristic internet and other characteristic towns[5]. In August 2017, the Ministry of Housing and Urban-Rural Development released the list of the second batch of 276 characteristic towns in China.

The characteristic town is a new organizational form of industrial space when China's social economy enters the transformation and innovative development stage[6],

${ }^{\text {a} E-m a i l ~ a d d r e s s: ~ t a n q q @ c n i s . a c . c n ~}$ 
which aims to improve the urban-rural development pattern, promote the economic transformation and upgrading and drive the new urbanization and rural revitalization[7]. With innovation as the base point, the industrial innovation and industrial upgrading are robustly developed, so as to coordinate the economic development and environmental protection, and facilitate the healthy and sustainable economic development of China[8].

\section{Current Standardization in China's Characteristic Towns}

Since the comprehensive construction of characteristic towns, the ministries and commissions and some provinces and municipalities of China have issued the policy documents for supporting the development of characteristic towns, covering the guiding thought, basic principle and basic requirement for the construction of characteristic towns.

- For instance, according to the Circular on Establishing the Mechanism for Characteristic Towns and High-quality Development of Characteristic Towns printed and distributed by the National Development and Reform Commission, the characteristic town construction should regard guiding the development of characteristic industry as the core, and a series of indicators related to the construction, development and evaluation of characteristic towns are put forward.

- In the Measures for Acceptance Naming of Characteristic Towns in Zhejiang, the appraisal indicators of characteristic towns are divided into "common indicator" and "characteristic indicator" (2 key factors), including 5 Level 1 indicators, namely, "gathered and combined" function, "small and beautiful" form, "new and flexible" system, "special and strong" industry, and open innovative characteristic work.

- In the rules for scoring of cultural and tourist characteristic towns of Sichuan Province, the cultural and tourist characteristic towns are evaluated in 7 aspects, namely, human resources, development planning, cultural and tourist characteristic industrial system, comprehensive benefit of cultural and tourist industry, public service infrastructure, market regulation and work safety, and brand building.

- In the dynamic assessment indicator system at the cultivation stage of characteristic towns of Guangxi, 4 basic assessment indicators (namely, characteristic town planning compilation, construction model, investment, and organization and implementation), 6 dynamic assessment indicators (namely, investment attraction, cultural digging, intelligentization construction, town marketing, project start-up and industrial development), and 5 additional score assessment indicators (namely, mechanism innovation, talent building, intellectual support, overall advancement of major project at the autonomous region level, and other honors) are included.

According to the detailed combing of the documents of the National Development and Reform Commission, the Ministry of Housing and Urban-Rural Development and other relevant ministries and commissions, and about 20 provinces and municipalities, including Zhejiang, Fujian and Anhui, on supporting and standardizing the construction, development and evaluation of characteristic towns, different documents have different requirements for creating the characteristic towns. According to the analysis on the abovementioned documents, most documents have raised the requirements for the industrial scale, economic level, living environment, service capacity, risk control, ecological protection and other indicators of characteristic towns. However, no uniform evaluation indicator system of China has taken shape.

In terms of establishment of standards, according to the retrieval, only local standards have requirements for characteristic towns presently(refer to Table 1). There are no special national standards and industrial standards for characteristic towns, especially the evaluation standards for development level of characteristic town.

Table1. Relevant Local Standards for Characteristic Towns

\begin{tabular}{|c|c|c|c|c|}
\hline $\mathbf{S} / \mathbf{N}$ & $\begin{array}{l}\text { Standard } \\
\text { No. }\end{array}$ & Standard & State & Level \\
\hline 1 & $\begin{array}{l}\mathrm{DB} 11 / \mathrm{T} \\
1465- \\
2017\end{array}$ & $\begin{array}{l}\text { Standard for } \\
\text { Facilities and } \\
\text { Services of Tourist } \\
\text { Characteristic } \\
\text { Towns }\end{array}$ & Current & $\begin{array}{l}\text { Local } \\
\text { Standard }\end{array}$ \\
\hline 2 & $\begin{array}{l}\mathrm{DB} 13 / \mathrm{T} \\
5032- \\
2019\end{array}$ & $\begin{array}{l}\text { Standard for } \\
\text { Facilities and } \\
\text { Services of Tourist } \\
\text { Towns }\end{array}$ & Current & $\begin{array}{l}\text { Local } \\
\text { Standard }\end{array}$ \\
\hline 3 & $\begin{array}{l}\mathrm{DB} 33 / \mathrm{T} \\
2089- \\
2017\end{array}$ & $\begin{array}{l}\text { Standard for } \\
\text { Appraisal of } \\
\text { Characteristic } \\
\text { Towns }\end{array}$ & Current & $\begin{array}{l}\text { Local } \\
\text { Standard }\end{array}$ \\
\hline 4 & $\begin{array}{l}\text { DB34/T } \\
2764- \\
2016 \\
\end{array}$ & $\begin{array}{l}\text { Regulations for } \\
\text { Appraisal of Tourist } \\
\text { Towns }\end{array}$ & Current & $\begin{array}{l}\text { Local } \\
\text { Standard }\end{array}$ \\
\hline 5 & $\begin{array}{l}\text { DB3509/T } \\
001-2019\end{array}$ & $\begin{array}{l}\text { Grading and } \\
\text { Appraisal of } \\
\text { Tourist Towns of } \\
\text { Ningde }\end{array}$ & Current & $\begin{array}{l}\text { Local } \\
\text { Standard }\end{array}$ \\
\hline 6 & $\begin{array}{l}\text { DB46/T } \\
450-2017\end{array}$ & $\begin{array}{l}\text { Identification of } \\
\text { Tourist Towns }\end{array}$ & Current & $\begin{array}{l}\text { Local } \\
\text { Standard }\end{array}$ \\
\hline
\end{tabular}

- In the Standard for Appraisal of Characteristic Towns, the appraisal content and indicator system of characteristic towns are mainly divided into "common indicator" and "characteristic indicator" (two key parts). The common indicator is composed of "gathered and combined" function, "small and beautiful" form and "new and flexible" system (three Level 1 indicators), with the total scores of 400. The characteristic indicator is composed of "special and strong" industry and open innovative characteristic work (two Level 1 indicators), with the total scores of 600 .

The Standard for Appraisal of Characteristic Towns may be regarded as the comprehensive evaluation indicator system of regional characteristic towns.

The Regulations for Appraisal of Tourist Towns and the like evaluate the characteristic towns where the tourist 
industry is the key industry.

At present, there are no special national or industrial standards for characteristic towns. Experience can only be learnt from the domestic policy documents, local standards or research report indicator systems.

Due to large regional differences in China, the development level of characteristic town is uneven and it is relatively low overall. Besides, China lacks the systematic and in-depth study on the development level evaluation of characteristic towns by standardization theory and working method presently. As a result, the standardization construction is restricted and the job demand for improving the development level of characteristic town cannot be met. Therefore, establishing the evaluation standard for development level of characteristic towns has great significances for improving the quality of development level of characteristic town, standardizing the development level of characteristic town, and enhancing the development level of characteristic towns. In December 2019, the Evaluation Indicator System for Development Level of Characteristic Towns (Program No. 20194487-T-424) which is put forward and under the centralized management by China National Institute of Standardization officially issued a project approval notice, which will fill in the gap of deficiency of national standard in the future.

\section{Suggestions}

Standardization is an important tool to manage, standardize and select the characteristic towns. Establishing the scientific, reasonable and effective standard is an important base for improving the development level of characteristic towns. However, the construction of standard system for development level of characteristic town lags behind. At present, there are almost no corresponding national or industrial supporting standards. Primarily, this is manifested in the fact that no uniform or authoritative evaluation standard for development level of characteristic towns has been released.

Therefore, put forward the following Suggestions for the standardization of characteristic towns.

(1) According to the type, feature, development model and the like of characteristic towns, the establishment of relevant national standards for characteristic towns meeting China's national conditions should be accelerated, the basic requirements for characteristic town construction should be raised, and the development level of characteristic town construction should be uniformly evaluated, in order to improve the overall level of characteristic town construction and drive the healthy development of characteristic town construction.

(2) The standard publicity by the standard user should be enhanced, the standardization awareness of relevant entities should be raised, and the good standardization atmosphere for understanding and applying the standard should be built so that the standard plays the real role.

(3) During the standard implementation, according to the standard, the list of powers and responsibilities of relevant departments should be formulated, the responsibilities for characteristic town construction should be further solidified, and the issuance efficiency of evaluation policy for development level of characteristic towns should be improved.

(4) It is required to construct the monitoring and evaluation database of characteristic towns, so as to provide strong support for the implementation of evaluation system. Due to the administrative division of characteristic towns, many statistical indicators have not reached the town level. The characteristic town is only an area, and it is also relatively difficult in the indicator statistics. In the implementation of evaluation system in the future, it is required to consider the establishment of suitable statistical system.

In the actual construction, the connotation and essence of characteristic towns should be accurately grasped, and the starting point of characteristic towns should be deeply understood. Starting from the overall development of the town, the regional characteristics are highlighted, and characteristic is not simply regarded as a regional element in the advancement[9]. The town construction, production and culture are really integrated. On the basis of town construction and development, more importance are attached to the industrial development features, style and function of characteristic building, inheritance of cultural heritage, and perfect supporting facilities and services. While the innovation is carried out, the system and mechanism vigor is enhanced to further promote the sustainable development of characteristic town.

\section{Conclusion}

The construction of characteristic towns has become a national strategy. This is an effective trial to innovate the structural reform of supply side, innovates and explores a new urbanization development model, promotes the economic upgrading and transformation, and is a new important starting point of mass start-up and innovation. This marks that China's town construction and development are faced with new major opportunities. Different regions should seize the development opportunities, act according to the circumstances, and highlight the development characteristics reliant on own long-standing cultural accumulation, unique ecological environment and good industrial base.

While China robustly boosts the construction of characteristic towns, it is necessary to establish the scientific indicator system, and conduct the evaluation and service decision-making by data, so as to provide a basis for improving the development level of characteristic towns.

\section{Acknowledgment}

Subsidy Project: "Preliminary Research on Standard System for New Urbanization Development Evaluation" (Project No.: 562019C-6983), Special Project on Standard Technology Management of the State Administration for Market Regulation. 


\section{References}

1. Wei Longbao, Shi Xinjie. Several Thoughts and Suggestions on Characteristic Town Construction in Zhejiang. [J]. Zhejiang Social Sciences, 2016(3): 2832.

2. Min Xueqin. Characteristic Town and Its Creation Path from the Perspective of Targeted Governance. [J]. Journal of Tongji University (Social Science Section), 2016, 27(5):55-60.

3. Wu Yueyao.Research on Landscape Evaluation of Knowledge Service Characteristic Towns in Hangzhou. [D].Zhejiang University 2019.

4. Bai Xue. Research on Creation and Advancement Path of Characteristic Towns in Inner Mongolia-Take Three Typical Characteristic Towns as an Example. [D].Inner Mongolia University, 2019.

5. Chen Mingman.Research on the Evolution of Characteristic Town from the Perspective of Complex Adaptive System. [D]. Chongqing University, 2018.

6. Zhang Min. Research on the Evolution of Characteristic Town from the Perspective of Innovative Ecological System. [D]. Suzhou University, 2018.

7. Wang Yufeng.Research on Planning Strategy for Scenic Spot Based Characteristic Town from the Perspective of Collaboration. [D]. Chongqing University, 2018.

8. Chen Xiaozhen. Research on Selection of Leading Industry in China's Characteristic Town. [D].Shandong Jianzhu University, 2017.

9. Shan Yanming, Ma Huijia, Song Wenjie.Cultivation Strategy and Development Suggestions of the National Characteristic Towns.[J]. Development of Small Cities \& Towns, 2016, (11):20-24. 